\title{
Stimulato-Inhibitory Response to Cumin Oil in Aflatoxin B1 Production of Aspergillus Species
}

\author{
Mohammad Hadi Fakoor ${ }^{1,{ }^{*}}$, Iraj Rasooli ${ }^{2}$, Parviz Owlia ${ }^{3}$, Mansooreh Mazaheri ${ }^{4}$, Fataneh \\ Shokrollahi ${ }^{4}$, Hossein Mohammadpour ${ }^{5}$, Sara Shehni Moosaie ${ }^{5}$, Zeynab Jalili ${ }^{5}$ \\ ${ }_{2}^{1}$ Department of Microbiology, Hidaj Branch, Islamic Azad University, Hidaj, IR Iran \\ 2 Department of Biology, Shahed University, Tehran, IR Iran \\ 3 Molecular Microbiology Research Center, Shahed University, Tehran, IR Iran \\ 4 Department of Food and Agriculture, Institute of Standard and Industrial Research of Iran (ISIRI), Karaj, IR Iran \\ 5 Department of Microbiology, Masjed Soleiman Branch, Islamic Azad University, Masjed Soleiman, IR Iran \\ ${ }^{*}$ Corresponding author: Mohammad Hadi Fakoor, Department of Microbiology, Hidaj Branch, Islamic Azad University, Hidaj, IR Iran. Tel: +98-9124617814, Fax: +98-2151212601, E-mail: \\ hadi.fakoor@gmail.com, hadi.fakoor@hidajiau.ac.ir.
}

Received: July 11, 2012; Revised: August 14, 2012; Accepted: September 04, 2012

Background: Aspergillus species produce the highly toxic and carcinogenic metabolite, Aflatoxin B1 (AFB1), on food and agricultural commodities. Some natural products are known to inhibit aflatoxin production.

Objectives: With the aim of controlling aflatoxin production, the essential oils of Cuminum cyminum L. from the best known regions of Iran i.e. Alborz Mountain and Kerman region, were obtained by hydrodistillation.

Materials and Methods: Antifungal activities of the oils to inhibit growth and aflatoxin productivity of A. flavus PICC-AF39, A. flavus PICCAF24, and A. parasiticus NRRL-2999 were studied. Minimal inhibitory (MIC) and minimal fungicidal (MFC) concentrations of the oil were determined. Sub-MIC was selected for the measurement of aflatoxins B and G concentration. Samples were analyzed either using a high performance liquid chromatography (HPLC) method with some minor modifications. Aflatoxins (AFs) were determined by reverse-phase HPLC and fluorescence detector with post column derivatization (PCD) involving bromination.

Results: A significant reduction in Aflatoxin production was noted which was not due to the inhibitory effect but because of antifungal property of the oil. Interestingly, the oil promoted toxin production for the reasons yet to be investigated. The extent of aflatoxin production was dependent on the concentration of essential oil used. All toxin-producing fungi in this study produced higher amount of aflatoxin at low concentrations of the oil. $400 \mathrm{ppm}$ concentration of $C$. cyminum L. from Alborz Mountain increased aflatoxin production to over fourfold. Aflatoxin productivity was declined at high concentration of the oil.

Conclusions: Antimicrobial and antitoxigenic properties of natural products need a firmly established criterion before they could be offered to application.

Keywords: Aflatoxin; Aspergillus Flavus; A. Parasiticus, Antifungal; Essential Oil; Cuminum Cyminum L.

\section{Background}

The presence and growth of fungi in food may cause spoilage and reduce its quality and quantity. Some Aspergillus species are responsible for contamination of food and feed $(1,2)$. Aspergillus flavus, A. parasiticus and rarely A. nomius are able to produce aflatoxins in food and feed stuff. A. flavus produces only B aflatoxins. Aflatoxin B and $\mathrm{G}$ are produced by A. parasiticus. However aflatoxin B1 (AFB1) is the most potent carcinogen known in mammals, the risk assessment of which is very well established (35). Each year many compounds are introduced to global markets as preservatives. Herbal products are of the most popular preservatives. The use of medicinal plants and spices in the food and pharmaceutical industries are increasing. Scientific evidence is that the spices do have medicinal properties which alleviate symptoms or prevent disease.

Cuminum cyminum is one of the popular spices often used as a flavoring agent. China is an important exporter of this commodity besides its use in traditional medicine in the treatment of some ailments. C. cyminum is widely used in food (6). The use of natural antimicrobial compounds is important in the preservation of food and in the control of human and plant diseases of microbial origin (7). Today, many natural compounds have been identified to have antimicrobial activity (8-10), essential

Implication for health policy/practice/research/medical education:

Nowadays, the use of essential oils and herbs as flavorings and preservatives is growingin the food industry. Some essential oils have antimicrobial properties. Cumin oil is one of the essential oils that have antimicrobial properties. In our studies, Cuminum cyminum L. stimulated aflatoxins production by Aspergillus species at sub MIC. Therefore, serious attention is needed toward standardization of the essential oils used in food industry to prevent food spoilage and toxin production.

Copyright (c) 2013, Ahvaz Jundishapur University of Medical Sciences; Licensee Kowsar Ltd. This is an Open Access article distributed under the terms of the Creative Commons Attribution License (http://creativecommons.org/licenses/by/3.0), which permits unrestricted use, distribution, and reproduction in any medium, provided the original work is properly cited. 
oils being the most important of these compounds (11). C. cyminum essential oils possess useful antimicrobial and antioxidant properties. (12-14). Unfortunately, in the food industry, many preservatives were used for their pleasant flavors and antimicrobial properties. Toxicity and adverse side effects are important factors which need attention in the preservatives.

\section{Objectives}

In this study attempts were made to evaluate the response in aflatoxin B and G production of Aspergillus species to the essential oil of C. cyminum.

\section{Materials and Methods}

\subsection{Fungal Strains and Cultures}

The microorganisms used were A.flavus PICC-AF39, A. flavus PICC-AF24, and A. parasiticus NRRL-2999. All microorganisms are toxigenic. The microorganisms were maintained on Sabouraud Dextrose Agar (Merck, Germany) at $4{ }^{\circ} \mathrm{C}$. Spore suspensions were prepared and diluted in sterile yeast extract sucrose (YES) broth to a concentration of approximately 106 spores/ml. Spore population was counted using a haemocytometer. Subsequent dilutions were made from the above suspension, which were then used in the tests. YES broth also served as aflatoxin production medium (15).

\subsection{Chemicals}

Aflatoxin (AF) standards were from Sigma Chemical Company, The USA. A stock standard solution of AF at $10000 \mu \mathrm{g} / \mathrm{ml}$ in methanol was prepared and kept wrapped in aluminum foil at $-20{ }^{\circ} \mathrm{C}$. AF working solutions were prepared by dilution in the same solvent and stored in glass-stoppered tubes at zero ${ }^{\circ} \mathrm{C}$. All solvents used for the experiments (methanol, acetonitrile, deionized water) were HPLC grade.Aflatest immunoaffinity columns (IAC) were purchased from the Romer Company. HPLC column (C 18) was from the Waters, The USA.

\subsection{Determination of Mycelial Weight and Antifun- gal Analysis}

Various concentrations (200 ppm, 400 ppm, 600 ppm and $800 \mathrm{ppm}$ ) of the oil were added to $100 \mathrm{ml}$ of YES broth (Merck, Germany) containing 106spore/ml. The flasks were incubated at $28 \pm 2{ }^{\circ} \mathrm{C}$ for 12 days on an incubator. Flasks containing mycelia were filtered through preweighed Whatman filter No.1 and were then washed with distilled water. The mycelia were placed on preweighed Petri plates and were allowed to dry at $50{ }^{\circ} \mathrm{C}$ for $6 \mathrm{~h}$ and then at $40{ }^{\circ} \mathrm{C}$ over night. The net dry weight of mycelia was then determined. Three replicates were used for each treatment. The percentage mycelia inhibition was calculated by the equation: $\mathrm{I}=1-\mathrm{T} / \mathrm{C} \times 100$, where $\mathrm{I}$ is inhibition
(\%), C is the colony weight of mycelium from a control flask (mg), and $\mathrm{T}$ is the colony weight of mycelium from a test flask (mg) (16).

\subsection{Measurement of Aflatoxins}

\subsubsection{Aflatoxins Extraction}

Erlenmeyer flasks containing $50 \mathrm{ml}$ of Yeast Extract Sucrose (YES) broth and C. cyminum oil from the Alborz Mountain at concentrations lower than the MIC (200 ppm, $400 \mathrm{ppm}, 600 \mathrm{ppm}$ and $800 \mathrm{ppm}$ ) were inoculated with fungal spores to give 106 spores $/ \mathrm{ml}$. The flasks were then incubated at $28 \pm 2{ }^{\circ} \mathrm{C}$ for 12 days. Aflatoxin B1, B2, G1 and $\mathrm{G} 2$ were determined at the end of the incubation period. Aflatoxin extraction was performed routinely with solvent extraction as described by Razzaghi et al. (17) and Allameh et al. (18).

\subsubsection{Extraction and Clean Up}

Samples were analyzed either using a high performance liquid chromatography (HPLC) method (19) with some minor modifications.In HPLC analysis, the test portion was extracted with $200 \mathrm{ml}$ of methanol/water $(80 \mathrm{ml} / 20$ $\mathrm{ml}$ ). After filtration, the extract was diluted with water and filtered through glass microfiber filter. For cleanup of samples, Aflatest IACs were used. $10 \mathrm{ml}$ phosphate buffer saline (PBS) was passed through the IAC. $75 \mathrm{ml}$ of the filtrate was passed through the IAC at flow rate of ca. $1 \mathrm{drop} / \mathrm{s}$. The column was washed with $15 \mathrm{ml}$ water and dried by applying little vacuum. Finally, AFs were evaluated with methanol by the following procedure. First, 0.5 $\mathrm{ml}$ methanol was applied on the column which passed through by gravity. After $1 \mathrm{~min}$, the second portion of one $\mathrm{ml}$ methanol was applied and collected. The collection was diluted with water and analyzed by HPLC.

\subsubsection{AF Standards}

After preparation of standard solutions of individual $\mathrm{AF}$, the concentration of each one was determined using UV spectrophotometer. These standards were used to prepare mixed working standards for HPLC.

\subsubsection{Analysis of AFs Using HPLC}

AFs were determined by reverse-phase HPLC and fluorescence detector with postcolumnderivatization (PCD) involving bromination (20). HPLC system (pump 1525, florescence detector 2475, analytical column, Nova-packC18 $250 \times 4.6 \mathrm{~mm}: 4 \mu \mathrm{m}$ ) PCD (postcolumnderivatization) was achieved with a Kobra cell and addition of bromide to the mobile phase. After dilution of AF evaluate with water, $100 \mu \mathrm{l}$ was injected into HPLC. Mobile phase was water: methanol: acetonitrile (600:300:200, v/v/v) and 350 micro liter from nitric acid 4 mole/lit and $12 \mathrm{mg}$ of potassium bromide with a flow rate of $1 \mathrm{ml} / \mathrm{min}$. The fluores- 
cence detector was operated at an excitation wavelength of $365 \mathrm{~nm}$ and emission wavelength of $435 \mathrm{~nm}$. Each working day, a five-point calibration curve was built for each individual AF including aflatoxin B1 (AFB1), aflatoxin B2 (AFB2), aflatoxin G1 (AFG1), and aflatoxin G2 (AFG2) checked for the linearity and used for quantification of AFs in samples.

\subsubsection{Quality Assurance}

For evaluation of the reliability of the results of AF analysis, in addition to using validated methods, internal and external quality control experiments were performed.
Regarding internal quality control, the accuracy and precision of the methods were verified. In this regard, recoveries of AFB1 and AFB2 were recorded by analyzing a blank sample spiked at 5ng/g for each AFB1, $1 \mathrm{ng} / \mathrm{g}$ for each AFB2, $1 \mathrm{ng} / \mathrm{g}$ for each AFG1, and $1 \mathrm{ng} / \mathrm{g}$ for each AFG2. According to the recovery values, AF levels were corrected for recoveries.

\section{Results}

The effect of C. cyminum L. oil from Alborz Mountain on mycelial mass and aflatoxin production is shown in Tables 1 - 4 .

Table 1. Effect of the C. cyminum L. Essential Oil From the Alborz Mountain on Growth of A. flavus PICC-AF24 and Its Aflatoxin Productivity Against $106 \mathrm{CFU} / \mathrm{Ml}$ of Fungal Suspensions

\begin{tabular}{|c|c|c|c|c|c|c|c|}
\hline $\begin{array}{l}\text { Oilconcen- } \\
\text { tration, ppm }\end{array}$ & $\begin{array}{l}\text { Dry weight } \\
\text { of mycelium, } \\
\text { mg }\end{array}$ & $\begin{array}{l}\text { Aflatoxin B1, } \\
\text { ng/mL }\end{array}$ & $\begin{array}{l}\text { Aflatoxin B1 } \\
\text { (ng) Produc- } \\
\text { tion Per (mg) } \\
\text { Mycelial } \\
\text { Weight }\end{array}$ & $\begin{array}{l}\text { Aflatoxin B2, } \\
\mathrm{ng} / \mathrm{mL}\end{array}$ & $\begin{array}{l}\text { Aflatoxin B2 } \\
\text { (ng) Produc- } \\
\text { tion Per (mg) } \\
\text { Mycelial } \\
\text { Weight }\end{array}$ & $\begin{array}{l}\text { Total Afla- } \\
\text { toxin (ng/ } \\
\text { ml) }\end{array}$ & $\begin{array}{l}\text { Total Aflatox- } \\
\text { in Ratio(ng) } \\
\text { Production } \\
\text { Per (mg) } \\
\text { Mycelial } \\
\text { Weight }\end{array}$ \\
\hline $\mathbf{0}$ & 1390 & 160.18 & 0.115237 & 212.4 & 0.152806 & 372.58 & 0.268043 \\
\hline 200 & 1580 & 492.51 & 0.311715 & 639.39 & 0.404677 & 1131.9 & 0.716392 \\
\hline 400 & 1490 & 781.2 & 0.524295 & 605.36 & 0.406282 & 1386.56 & 0.930577 \\
\hline 600 & 1530 & 264.22 & 0.172693 & 81.79 & 0.053457 & 346.1 & 0.226209 \\
\hline 800 & 1000 & 9.08 & 0.00908 & 4.2 & 0.004200 & 13.28 & 0.013280 \\
\hline
\end{tabular}

Table 2. Effect of the .C. cyminum L. Essential Oil From the Alborz Mountain on Growth of A.flavus PICC-AF39 and Its Aflatoxin Productivity Against $106 \mathrm{CFU} / \mathrm{mL}$ of Fungal Suspensions

\begin{tabular}{llllllll}
\hline $\begin{array}{l}\text { Oilconcen- } \\
\text { tration, } \mathbf{p p m}\end{array}$ & $\begin{array}{l}\text { Dry Weight } \\
\text { of Mycelium, } \\
\mathbf{m g}\end{array}$ & $\begin{array}{l}\text { Aflatoxin B1, } \\
\mathbf{n g} / \mathbf{m L}\end{array}$ & $\begin{array}{l}\text { Aflatoxin B1 } \\
\mathbf{n g} \text { Produc- } \\
\text { tion Per }(\mathbf{m g}) \\
\text { Mycelial } \\
\text { Weight }\end{array}$ & $\begin{array}{l}\text { Aflatoxin B2, } \\
\mathbf{n g} / \mathbf{m L}\end{array}$ & $\begin{array}{l}\text { Aflatoxin B2 } \\
\text { (ng) Produc- } \\
\text { tion Per }(\mathbf{m g}) \\
\text { Mycelial } \\
\text { Weight }\end{array}$ & $\begin{array}{l}\text { Total Afla- } \\
\text { toxin, ng/mL }\end{array}$ & $\begin{array}{l}\text { Total Aflatox- } \\
\text { in Ratio(ng) } \\
\text { Production } \\
\text { Per(mg) } \\
\text { Mycelial } \\
\text { Weight }\end{array}$ \\
\hline $\mathbf{0}$ & 410 & 1.05 & 0.002561 & 0.06 & 0.000146 & 1.11 & 0.002708 \\
$\mathbf{2 0 0}$ & 350 & 2.28 & 0.006514 & 0.48 & 0.001371 & 2.76 & 0.007886 \\
$\mathbf{4 0 0}$ & 330 & 4.33 & 0.013121 & 1.51 & 0.004576 & 5.84 & 0.017697 \\
$\mathbf{6 0 0}$ & 210 & 3.1 & 0.014762 & 0.99 & 0.004714 & 4.09 & 0.019476 \\
$\mathbf{8 0 0}$ & 180 & 1.56 & 0.008667 & 0 & 0.000000 & 1.56 & 0.008667 \\
\hline
\end{tabular}

Table 3. Effect of the C. cyminum L. Essential Oil From the Alborz Mountain on Growth of A. Parasiticus NRRL-2999 and Its Aflatoxin B Productivity Against $106 \mathrm{CFU} / \mathrm{mL}$ of fungal Suspensions

\begin{tabular}{llllllll}
\hline $\begin{array}{l}\text { Oilconcen- } \\
\text { tration, ppm }\end{array}$ & $\begin{array}{l}\text { Dry Weight } \\
\text { of Mycelium, } \\
\text { mg }\end{array}$ & $\begin{array}{l}\text { Aflatoxin B1, } \\
\mathbf{n g} / \mathbf{m L}\end{array}$ & $\begin{array}{l}\text { Aflatoxin } \\
\text { B1(ng) Pro- } \\
\text { duction Per } \\
\text { (mg) Myce- } \\
\text { lial Weight }\end{array}$ & $\begin{array}{l}\text { Aflatoxin B2, } \\
\mathbf{n g} / \mathbf{m L}\end{array}$ & $\begin{array}{l}\text { Aflatoxin } \\
\text { B2(ng) Pro- } \\
\text { duction Per } \\
\text { (mg) Myce- } \\
\text { lial Weight }\end{array}$ & $\begin{array}{l}\text { Total Afla- } \\
\text { toxin, ng/mL }\end{array}$ & $\begin{array}{l}\text { Total Aflatox- } \\
\text { in ratio(ng) } \\
\text { Production } \\
\text { per(mg) } \\
\text { Mycelial } \\
\text { Weight }\end{array}$ \\
\hline $\mathbf{0}$ & 630 & 31.70 & 0.0503175 & 0.83 & 0.0013175 & 46.61 & 0.0739841 \\
\hline $\mathbf{2 0 0}$ & 500 & 139.97 & 0.27994 & 4.48 & 0.00896 & 226.71 & 0.45342 \\
\hline $\mathbf{4 0 0}$ & 410 & 116.76 & 0.2847805 & 6.85 & 0.0167073 & 158.58 & 0.3867804 \\
\hline $\mathbf{6 0 0}$ & 400 & 113.21 & 0.283025 & 10.41 & 0.026025 & 193.66 & 0.48415 \\
\hline $\mathbf{8 0 0}$ & 350 & 141.65 & 0.4047143 & 4.83 & 0.0138 & 233.11 & 0.6660285 \\
\hline
\end{tabular}


Table 4. Effect of the C. cyminum L. Essential Oil From the Alborz Mountain on Growth of A. Parasiticus NRRL-2999 and its Aflatoxin G Productivity Against $106 \mathrm{CFU} / \mathrm{mL}$ of Fungal Suspensions

\begin{tabular}{llllll}
\hline $\begin{array}{l}\text { Oilconcentration, } \\
\text { ppm }\end{array}$ & $\begin{array}{l}\text { Dry Weight of } \\
\text { Mycelium, } \mathbf{m g}\end{array}$ & $\begin{array}{l}\text { Aflatoxin G1(ng/ } \\
\mathbf{m L})\end{array}$ & $\begin{array}{l}\text { Aflatoxin G1(ng) } \\
\text { Production Per } \\
\text { (mg) Mycelial } \\
\text { Weight }\end{array}$ & $\begin{array}{l}\text { Aflatoxin G2, ng/ } \\
\text { mL }\end{array}$ & $\begin{array}{l}\text { Aflatoxin G2 (ng) } \\
\text { Production Per } \\
\text { (mg) Mycelial } \\
\text { Weight }\end{array}$ \\
\hline $\mathbf{0}$ & 630 & 14.08 & 0.0223492 & 0.00 & 0.00 \\
\hline $\mathbf{2 0 0}$ & 500 & 82.00 & 0.164 & 0.26 & 0.00052 \\
$\mathbf{4 0 0}$ & 410 & 34.09 & 0.0831463 & 0.88 & 0.0021463 \\
\hline $\mathbf{6 0 0}$ & 400 & 69.25 & 0.173125 & 0.79 & 0.001975 \\
$\mathbf{8 0 0}$ & 350 & 84.95 & 0.2427143 & 1.68 & 0.0048 \\
\hline
\end{tabular}

The scores related to AFB1, AFB2, AFG1 and AFG2 were used for a linear regression in the standard. HPLC analysis of spiked samples gave a good correlation with spiked values ( $\mathrm{R} 2>0.992)$. The scores regression coefficient $(\mathrm{R} /$ R2) for AFB1, AFB2, AFG1 and AFG2 were0.9965/0.9930, $0.9963 / 0.9926,0.9981 / 0.9962$ and $0.9996 / 0.9992$ respectively.

The concentration of essential oil to inhibit production of aflatoxin (B1, B2 and total) for A. flavus PICC-AF39, A. flavus PICC-AF24, and (B1, B2, G1, G2 and total) for A. parasiticus NRRL-2999 was determined to be in the range of sub-MIC (200 ppm, 400 ppm, 600 ppm and 800 ppm). Mycelia weight declined with increasing concentration of essential oil showed in Tables 1-3. We can clearly show an increase in aflatoxin production by all three species of toxin-producing Aspergillus (Tables 1, 4). Whereas dry weight of mycelium(mg) of A. flavus PICC-AF39, A. flavus PICC-AF24 and A. parasiticus NRRL-2999 was declined (Tables 1,3).

Dry weight of mycelium (mg) of A. flavus PICC-AF24 in $800 \mathrm{ppm}$ concentration declined $28.06 \%$ compared to control without oil (Table 1). In this Table, at $400 \mathrm{ppm}$ concentration of C. cyminum L. essential oil from Alborz Mountain, the concentration of aflatoxin B1, B2 and total aflatoxin were 4.55, 2.66 and 3.47 fold respectively. The same happened in A. flavus PICC-AF39 at 800 ppm and $400 \mathrm{ppm}$ for dry weight of mycelium and aflatoxin production (B1 and B2) respectively. At $800 \mathrm{ppm}$ oil concentration the mycelium weight reduced to $56.1 \%$. At 400 $\mathrm{ppm}$, aflatoxin B1, B2 and total production were increased $5.76,2.66$ and 6.54 fold respectively (Table 2).

Tables 3 and 4 show oil concentration of the Alborz Mountain C. cyminum L. (ppm), dry weight of mycelium, aflatoxins (B1, B2, G1, G2 and total) (ng/mL) and Aflatoxins production (B1, B2, G1, G2 and total) (ng) per (mg) mycelia weight for A. parasiticus NRRL-2999. The mycelial dry weight compared to control without oil calculated at 800 ppm was lost (Table 3). Toxin production was increased by A. parasiticus NRRL-2999 at $800 \mathrm{ppm}$ of the oil.Aflatoxin production (B1, B2, G1and total)(ng) per (mg) mycelia weight were increased to $8,19,10.86$, and 9 fold respectively.

A. parasiticus NRRL-2999 does not produce G2 toxin pro- duction under normal conditions. When oil was added to the flask containing fungal spores of A. parasiticus , AFG1 was produced and increased to about 10-fold (Table 4). The extent of aflatoxin production was dependent on the concentration of essential oil used (Tables 2, 3). All toxinproducing fungi in this study produced higher amount of aflatoxin at low concentrations of the oil. Aflatoxin productivity was declined at high concentration of the oil (Table 1, 4).

\section{Discussion}

Antifungal activities of C. cyminum L. essential oilfrom the Alborz Mountain against A. flavus PICC-AF39, A. flavus PICC-AF24 and A. parasiticus NRRL-2999 was determined (14). Minimal inhibitory (MIC) and minimal fungicidal (MFC) concentrations (ppm) of the C. cyminum L. essential oil from the Alborz mountain of Iran against 106 spores $/ \mathrm{ml}$ of A. flavus PICC-AF24, PICC-AF39 and A. parasiticus NRRL-2999 were 1000/3000, 1000/2500 and 750/3000 ppm respectively ( 14 ). Our results of antifungal properties are in agreement with those reported by Mohammadpour et al. (14). Mycelia weight declined with increasing concentration of C. cyminum L. from the Alborz Mountain (Tables 1-3).

Antimicrobial activity of Cumin oil on some bacteria and fungi has been reported $(21,22)$. Although expression of antifungal activity is often very clear, the mechanism of action is ambiguously understood. Therefore, further research is to be performed to determine the antimicrobial activity of $C$. cyminum $\mathrm{L}$. The oils exhibited significant inhibition of fungal growth and aflatoxin B1 production. Turmeric leaf oil exhibited $95.3 \%$ and $100 \%$ inhibition of aflatoxin production respectively at $1.0 \%$ and $1.5 \%$ concentrations in YES broth (23). Bhanu Prakash et al.,(24) showed antifungal properties of Piper betle L. essential oil (EO) in fungal contamination on some dry fruits. MIC of P. betle L. was found to be $0.7 \mu \mathrm{l} / \mathrm{ml}$ against A. flavus. The EO reduced AFB1 production at $0.6 \mu \mathrm{l} / \mathrm{ml}$. They reported efficacy of $P$. betle $\mathrm{EO}$ as aflatoxin suppressor.

A finding showed that aflatoxin production can be controlled by costoring whole sweet basil leaves (Ocimum basilicum) with aflatoxin infected foods (25). There are other studies that have confirmed above $(15,26-28)$. 
Fakoor MH et al.

On the other hand, the compounds are also stimulates for aflatoxin production by toxin-producing fungi. Our research showed that Cumin essential oil from Alborz Mountain had stimulating effect on toxin productivity of A. flavus PICC-AF24, A. flavus PICC-AF39 and A. parasiticus NRRL-2999. This strange phenomenon is being reported for the first time. Since most essential oils have been found to be cytotoxic rather than mutagenic, it is likely that most of them are noncarcinogenic. Some metabolites are genetically induced by some essential oils. Lower concentrations of the cytotoxic effect can induce the production of secondary metabolites in Saccharomyces cerevisiae (29-31).

Aflatoxins are also secondary metabolites. However, some essential oils or rather some of their constituents may be considered as secondary carcinogens after metabolic activation. For example, essential oils like those from Salvia sclarea and Melaleuca quinquenervia provoke estrogen secretions which can induce estrogen-dependent cancers $(32,33)$. In conclusions serious attention is needed toward standardization of the essential oils used in food industry to prevent food spoilage and toxin production.

\section{Acknowledgements}

This study was fully supported by the Vice chancellor for Research of Hidaj, Azad University.

\section{Authors' Contribution}

Study concept, design and the protocol: Fakoor, Rasooli and Owlia; Reverse-phase HPLC and analysis of HPLC for toxin assay: Fakoor, Rasooli, Owlia, Mazaheri and Shokrollahi; Manual techniques for microbiology: Fakoor, Shehni, Jalilli and Mohammadpour; Wrote the manuscript: Fakoor and is guarantor

\section{Financial Disclosure}

None declared.

\section{Funding/Support}

This study was financially supported by Azad University (Hidaj branch).

\section{References}

1. Abarca ML, Bragulat MR, Castella G, Cabanes FJ. A Research Note: Mycoflora and Aflatoxin-Producing Strains in Animal Mixed Feeds. J Food Protect. 1994;57(3):256-8.

2. Katta SarathK, Eskridge KentM, Bullerman LloydB. Mold Content of Commercial Popcorn. J Food Protect. 1995;58(9):1014-7.

3. Diener UL, Davis ND. Aflatoxin production by isolates of Aspergillus flavus. Phytopathology. 1966;56(12):1390-3.

4. Guo BZ, Russin JS, Brown RL, Cleveland TE, Widstrom NW. Resistance to aflatoxin contamination in corn as influenced by relative humidity and kernel germination.JFood Prot.1996;59(3):27681.

5. Hussein HusseinS, Brasel JeffreyM. Toxicity, metabolism, and impact of mycotoxins on humans and animals. Toxicology.
2001;167(2):101-34.

6. Li Rong, Jiang Zi-Tao. Chemical composition of the essential oil of Cuminum cyminum L. from China. Flavour Frag J. 2004;19(4):3113.

7. Baratta MTiziana, Dorman HJDamien, Deans Stanley G, Figueiredo ACristina, Barroso José G, Ruberto Giuseppe. Antimicrobial and antioxidant properties of some commercial essential oils. Flavour Frag J.1998;13(4):235-44.

8. Nguefack J, Leth V, Amvam Zollo PH, Mathur SB. Evaluation of five essential oils from aromatic plants of Cameroon for controlling food spoilage and mycotoxin producing fungi. Int J Food Microbiol. 2004;94(3):329-34.

9. Fakoor Mohammad, Pipelzadeh MohammadHassan. A Stuy on the Healing Effect of Honey on Infected Open Fracture Wound. PakJ Med Sco. 2007;23(3):327-9.

10. Weckesser S, Engel K, Simon-Haarhaus B, Wittmer A, Pelz K, Schempp CM. Screening of plant extracts for antimicrobial activity against bacteria and yeasts with dermatological relevance. Phytomedicine. 2007;14(7-8):508-16

11. Soliman KM, Badeaa RI. Effect of oil extracted from some medicinal plants on different mycotoxigenic fungi. Food Chem Toxicol. 2002;40(11):1669-75.

12. Fakoor MH, Rasouli I. Pathogen Control by Antioxidative Characteristics of Cuminum Cyminumand Rosmarinus Officinalis Essential Oils. Acta Hort. 2008;768:125-36.

13. Oroojalian F, Kasra-Kermanshahi R, Azizi M, Bassami MR. Phytochemical composition of the essential oils from three Apiaceae species and their antibacterial effects on food-borne pathogens. Food Chem. 2010;120(3):765-70.

14. Mohammadpour H, Moghimipour E, Rasooli I, Fakoor MH, Alipoor Astaneh S, Shehni Moosaie S, et al. Chemical Composition and Antifungal Activity of Cuminum cyminum L. Essential Oil From Alborz Mountain Against Aspergillus species. Jundishapur J Nat Pharm Prod. 2012;7(2):50-5.

15. Rasooli I, Fakoor MH, Allameh AA, Rezaee MB, Owlia P. Phytoprevention of aflatoxin production. J Med Plans. 2009;8(5):97-104.

16. Rasooli I, Fakoor MH, Yadegarinia D, Gachkar L, Allameh A, Rezae MB. Antimycotoxigenic characteristics of Rosmarinus officinalis and Trachyspermum copticum L. essential oils. Int J Food Microbiol. 2008;122(1-2):135-9.

17. Razzaghi Abyaneh M, Allameh A, Shams M. Screening of Aflatoxin-producing mould isolates based on fluorescence production on a specific medium under ultraviolet light. Acta Med Iran. 2000;38(2):67-73

18. Allameh A, Abyaneh MRazzaghi, Shams MRazzaghi, Rezaee MB Jaimand K. Effects of neem leaf extract on production of aflatoxins and activities of fatty acid synthetase, isocitrate dehydrogenase and glutathione S-transferase in Aspergillus parasiticus. Mycopathologia. 2002;154(2):79-84

19. Food stuffs, Determination of aflatoxins by HPLC and clean up by IAC 2004 .

20. Stroka Jörg, Otterdijk Robertvan, Anklam Elke. Immunoaffinity column clean-up prior to thin-layer chromatography for the determination of aflatoxins in various food matrices. J Chromatography A. 2000;904(2):251-6.

21. Hajlaoui H, Mighri H, Noumi E, Snoussi M, Trabelsi N, Ksouri R, et al. Chemical composition and biological activities of Tunisian Cuminum cyminum L. essential oil: a high effectiveness against Vibrio spp. strains. Food Chem Toxicol. 2010;48(8-9):2186-92.

22. Iacobellis NS, Lo Cantore P, Capasso F, Senatore F. Antibacteria activity of Cuminum cyminum L. and Carum carvi L. essential oils. J Agric Food Chem. 2005;53(1):57-61.

23. Sindhu S, Chempakam B, Leela NK, Suseela Bhai R. Chemoprevention by essential oil of turmeric leaves (Curcuma longa L.) on the growth of Aspergillus flavus and aflatoxin production. Food Chem Toxicol. 2011;49(5):1188-92.

24. Prakash B, Shukla R, Singh P, Kumar A, Mishra PK, Dubey NK. Efficacy of chemically characterized Piper betle L. essential oil against fungal and aflatoxin contamination of some edible commodities and its antioxidant activity. Int J Food Microbiol. 2010;142(1-2):114-9.

25. Atanda OO, Akpan I, Oluwafemi F. The potential of some spice es- 
sential oils in the control of A. parasiticus CFR 223 and aflatoxin production. Food Control. 2007;18(5):601-607.

26. Bluma RV, Etcheverry MG. Application of essential oils in maize grain: impact on Aspergillus section Flavi growth parameters and aflatoxin accumulation. Food Microbiol. 2008;25(2):324-34.

27. Shukla R, Kumar A, Singh P, Dubey NK. Efficacy of Lippia alba (Mill.) N.E. Brown essential oil and its monoterpene aldehyde constituents against fungi isolated from some edible legume seeds and aflatoxin B1 production. Int J Food Microbiol. 2009;135(2):165-70.

28. Sidhu OP, Chandra H, Behl HM. Occurrence of aflatoxins in mahua (Madhuca indica Gmel.) seeds: synergistic effect of plant extracts on inhibition of Aspergillus flavus growth and aflatoxin production. Food Chem Toxicol. 2009;47(4):774-7.
29. Averbeck D, Averbeck S, Dubertret L, Young AR, Morlière P. Genotoxicity of bergapten and bergamot oil in Saccharomyces cerevisiae. J Photoch Photobio B. 1990;7(2-4):209-29.

30. Averbeck Dietrich, Averbeck Simone. Induction of the genes RAD54 and RNR2 by varoius DNA damaging agents in Saccharomyces cerevisiae. Mutat Res-DNA Repair.1994;315(2):123-38.

31. Dardalhon M, Agoutin B, Watzinger M, Averbeck D. Slt2 (Mpk1) MAP kinase is involved in the response of Saccharomyces cerevisiae to 8-methoxypsoralen plus UVA. J Photochem Photobiol B. 2009;95(3):148-55.

32. Cuba Ron. Toxicity myths essential oils and their carcinogenic potential. Intl J Aromatherapy. 2001;11(2):76-83.

33. Bakkali F, Averbeck S, Averbeck D, Idaomar M. Biological effects of essential oils-a review. Food Chem Toxicol. 2008;46(2):446-75. 